\title{
Evaluation of Demographic Variables on the Knowledge and Prevention of Cholera: A Case Study of Durumi, Abuja, Nigeria
}

\author{
ANETOR, GO \\ Human Kinetics and Health Education Department, Faculty of Education, National Open University of Nigeria, Abuja \\ Corresponding Author Email: yahuanet@yahoo.com
}

\begin{abstract}
ABSRACT: Cholera remains a disease of public health importance globally and particularly in the developing countries including Nigeria. This study evaluated demographic characteristics (age, gender, educational level, religion) in Durumi community in relation to the knowledge and prevention of cholera so as to adequately report them and proffer solutions to reduce the disease occurrence by selecting 360 participants. Data obtained were analyzed using descriptive statistics of percentages (\%), frequency counts and mean. Inferential statistics of T-test, ANOVA and regression used to analyze the variables at 0.05 significant levels. Age had significant influence on knowledge $(\mathrm{p}=\mathrm{v} 0.02)$ and prevention $(\mathrm{p}<0.021)$ of cholera. The younger people appeared to have more knowledge and prevention of cholera than the older people. Gender was significant to knowledge $(p=0.020)$ and prevention $(p$ $=0.044)$ of cholera. The educational level was also significant to knowledge $(p=0.000)$ and prevention $(p=0.000)$. Religion was significant to knowledge $(p=0.03$ and prevention $(p=0.004)$ of cholera. Demographic variables have significant effect on knowledge and preventive measures of cholera $\mathrm{P}$ value $<0.05$ in all variables tested. However, younger age group $(<50$ years), females contributed higher mean score, people with formal education, Christian and Muslims all appeared more knowledgeable and more in tuned with preventive measures of cholera. Therefore, there is the need to use targeted health education for advocacy for people with no formal education, above 50 years, and others on cholera knowledge and prevention.
\end{abstract}

DOI: $\underline{\text { https://dx.doi.org/10.4314/jasem.v24i5.26 }}$

Copyright: Copyright $(\subset) 2020$ Anetor. This is an open access article distributed under the Creative Commons Attribution License (CCL), which permits unrestricted use, distribution, and reproduction in any medium, provided the original work is properly cited.

Dates: Received: 15 March 2020; Revised: 25 April 2020; Accepted: 17 May 2020

Keywords: Demographic variables, cholera, Abuja, Health education.

Cholera remains a disease of public health importance globally and particularly in the developing countries including Nigeria. The disease is caused by the bacterium vibrio cholerae which can be ingested in food or water contaminated by the bacterium, also common in places with poor sanitation. The sickness is characterized by severe diarrhoea leading to severe dehydration, vomiting, cramps, fever among others. Population density, urbanization, and overcrowding have been reported to influence cholera transmission (Adagbada et al., 2012; Dan -Nwafor et al., 2019; Elimian et al., 2019). Cholera appears to be a disease which strikes indiscriminately of sex, age, education and religious status and other socio-demographic variables. However, these factors may contribute to an individual's vulnerability to the disease, by determining the social roles and behaviours he or she is expected to conform to, which may subsequently affect exposure to the disease. It appears like the linkages between age, gender, education, religion; other socio demographic variables and vulnerability to cholera have not been well understood. Previous studies have reported interaction between demographic variables and cholera. A society that adheres to strict gender roles in the domestic, productive, and community settings, transmission routes are likely to be sex and age-specific (Wahed et. al., 2013; Stoltzfus et al., 2014; Ncube et al., 2016). Cholera is a pandemic disease commoner in developing countries. In Nigeria, as of 9 September 2018, a total of 27927 suspected cases including 517 deaths (CFR 1.9\%) have been reported from 19 States. It was also confirmed that there was an overall increasing trend in the number of reported cases (United Nations Office for the Coordination of Humanitarian Affairs (OCHA), 2017). The disease appears to affect more of the northern states in the country (Leckebusch \& Abdussalam, 2015). According to United Nations International Children's Emergency Fund (UNICEF) (2019), "the largest outbreaks were reported in the northern states of the country" Many reasons have been proffered and examined for the possible predisposing factors for the disease but not many studies in Nigeria have examined demographic variables in relation to the knowledge and preventive measures of the disease. There appears to be paucity of data on how demographic variables interact and contribute to cholera outbreaks in north central Nigeria as well as interfering with the knowledge and preventive measures of cholera in 
Durumi in particular. Therefore, this study examined four demographic characteristics (age, gender, educational level, religion) of the residents of Durumi community in the Federal Capital Territory (FCT) to evaluate the selected demographic variables in relation to the knowledge and prevention of cholera in order to proffer a possible solution to reduce the occurrence of the disease.

\section{MATERIALS AND METHODS}

Study Area: This study was conducted in Durumi community in the FCT Abuja. Durumi is situated in Abuja municipal, hence one of the fastest growing settlements in the city and still developing. The population of Durumi according to 2018 population estimate is twelve thousand nine hundred and sixty six; (National Population Commission (NPC), 2019; Abuja City Population, 2019). Among the predominant tribes are the Gwaris, Hausa, Igbo, Yoruba, Igala, Tiv and Idoma. The social amenities within the community include; Government primary school, junior secondary school, private clinic, bore holes, private nursery and primary schools, Churches, Mosque and River. Their major occupation is petty trading and farming while some are civil servants.

Design and Population: Descriptive survey design was employed to carry out the study. The study population was made up of all males and females who were eighteen years and above and resident at Durumi District Abuja. The study examined four demographic variables (age, gender, educational level, religion) in relation to the Knowledge and preventive measures. The data used was collected from the residents of Durumi who presented with significant knowledge and significant preventive measures of cholera in the study earlier carried out with the listed demographic variables being evaluated. A sample size of 330 was used for the study (171 females and 159 males). A validated self-structured questionnaire was the instrument for data collection and reliability coefficient of the instrument was $r=0.8$.

Data Analysis: Data analysis was carried out using descriptive statistics of percentages (\%), frequency counts and mean. The inferential statistics of T-test, ANOVA and regression were used to analyze the variables under study and $p$-value was set at 0.05 significant levels.

\section{RESULTS AND DISCUSSION}

Table 1 shows that majority of the participants (89) fall within the age range of 26 and 33 years; $18-25$ years (23.9\%); $34-41$ years $(17.9 \%) ; 17.3 \%$ were age range $42-49 ; 10 \%$ were between 50 and 57 years and the least (3.9\%) were within the age range of 58 years and above. Gender reveals that females were 171 and males were 159. Educational level of the participants shows that 148 (44.8\%) had secondary education; 133 (40.3\%) participants had tertiary education; $26(7.9 \%)$ participants had primary education and $23(7.0 \%)$ had no formal education. The religion of the participants reveals that two hundred and twenty-six $(68.5 \%)$ of them were practicing Christianity; Islam was being practiced by ninety-eight $(29.7 \%)$ participants; while only six $(1.8 \%)$ of the participants were into traditional religion.

Table 1: Demographic variables of participants

\begin{tabular}{lll}
\hline & Frequency & Percentages (\%) \\
\hline Age (in years) & & \\
1825 & 79 & 23.9 \\
$26-33$ & 89 & 27 \\
$34-41$ & 59 & 17.9 \\
$42-49$ & 57 & 17.3 \\
$50-57$ & 33 & 10 \\
58 and above & 13 & 3.9 \\
Gender & & \\
Male & 159 & 48 \\
Female & 171 & 52 \\
Educational level & & \\
Primary Education & 26 & 7.9 \\
Secondary Education & 148 & 44.8 \\
Tertiary education & 133 & 40.3 \\
No formal education & 23 & 7.0 \\
Religion & & \\
Christianity & 226 & 68.5 \\
Islam & 98 & 29.7 \\
Traditional & 6 & 1.8 \\
\hline \multicolumn{2}{c}{ Field Survey, 2019. } \\
\end{tabular}

The general view of the demographic variables shows that more young people reside in the community, which is the age group less than 50 years of age (table 1). The good number of young people in the community may help to share the knowledge they get through social media, their institutions and peers. This may give them the advantage to curbing cholera infection as they are easily informed are likely to be abreast of current knowledge which can be easily applied cholera prevention other health issues (Lamond and Kinyanjui, 2012). They are also supposed to be energetic enough to keep the environment clean because of their youthfulness. The gender shows more females than males; this may be advantageous for the community in a culture where the women are saddled with environmental cleanliness which is necessary to prevent cholera infection (Rancourt, 2013). According to Rancourt (2013), the linkages between gender and vulnerability to cholera are not well understood, but due to their gender roles, women possess the ability and influence to be able to protect family units from contamination. The people's educational status appears encouraging as majority of 
them have secondary and tertiary education. Education from their various institution of learning is likely to help them convey health messages to catchment localities quickly and effectively (Lamond \& Kinyanjui, 2012). They are likely to be abreast of current teachings and be able to understand better any information given concerning how to curtail cholera.
The community members are mainly Christians and Muslims; this finding was good to know as it may also help them to practice community-sprit better as preached by both religions. If they actually practice their religion well, they will be able to come together to assist each other in one love and through community effort they will be able to prevent cholera.

Ho1: There is no significant relationship of demographic variables (age, gender, education and religion) on the participants' knowledge of cholera disease.

Table 2a: Relationship between participants' age and knowledge of cholera disease.

\begin{tabular}{|c|c|c|c|c|c|}
\hline Model & Sum of Squares & df & Mean Square & $\mathbf{F}$ & Sig. \\
\hline Regression & 16.773 & 6 & 4.222 & 22.452 & $0.02^{\mathrm{a}}$ \\
\hline Residual & 304.147 & 324 & 2.028 & & \\
\hline Total & 320.920 & 330 & & & \\
\hline
\end{tabular}

(a) Predictors: (Constant), 18-25, 26-33, 34-41, 42-49, 50-57, 58+,

(b) Dependent variable: Knowledge of cholera, $R=.891^{a}, \quad R^{2}=.794 ; \quad$ Adj. $R^{2}=.770 ; P<.05$.

Table 2b: Regression Analysis of Participants' Age on Knowledge of Cholera Disease

\begin{tabular}{llllll}
\hline Model & \multicolumn{2}{l}{$\begin{array}{l}\text { Unstandardized } \\
\text { Coefficient }\end{array}$} & $\begin{array}{l}\text { Standardized } \\
\text { Coefficient }\end{array}$ & T & Sig. \\
& Beta & $\begin{array}{l}\text { Std. } \\
\text { Error }\end{array}$ & Beta & & \\
\hline (Constant) & 7.281 & 4.590 & & 4.210 & .000 \\
$18-25$ & 2.107 & .513 & .372 & 3.511 & .000 \\
$26-33$ & 1.571 & .631 & .329 & 2.784 & .003 \\
$34-41$ & 1.022 & .611 & .289 & 2.293 & .001 \\
$42-49$ & .532 & .484 & .191 & 2.187 & .002 \\
$50-57$ & .174 & .709 & .051 & .372 & .064 \\
$58+$ & .037 & .532 & .055 & .238 & .073 \\
\hline \multicolumn{7}{c}{ Dependent variable: Knowledge of cholera disease } \\
\end{tabular}

Table 2a shows the value of R-square is .794 which means that $79.4 \%$ variation in participants' knowledge of cholera disease was due to their ages. F-statistics was carried out to find the overall strength of the model. The value of F-statistics 22.452, $\mathrm{p}$ value 0.02 $(p<0.05)$ shows that there is significant knowledge of cholera among residents of Durumi community as regards their ages. In table $2 b$, regression analysis was carried out to further bring out where differences lie between age and knowledge of cholera. Table $2 b$ above shows the relative awareness of each of the age groups on the knowledge of cholera disease, i.e. 18-25 $(\beta=.372 ; \mathrm{P}<.05) ; 26-33(\beta=.329 ; \mathrm{P}<.05) ; 34-41(\beta$ $=.289 ; \mathrm{P}<.05) ; 42-49(\beta=.191 ; \mathrm{P}<.05) ; 50-57(\beta=$ $-.051 ; \mathrm{P}>.05)$ and $58+(\beta=.055 ; \mathrm{P}>.05)$. Hence, while age group 18-25, 26-33, 34-41 and 42-49 were significant, 50-57 and 58+ years were not. The first hypothesis tested the relationship of the demographic variables (age, gender, education and religion). The relationship between age and knowledge of cholera in the participants show that age is significantly related to knowledge of cholera (table $2 \mathrm{a}$ ). The younger age group had a better knowledge; that is the category of 18-49 years had knowledge of cholera disease, but those between 50 years and above had little or no knowledge of cholera disease (table 2b). This difference in knowledge may be due to the level at which they understand the questionnaire or as they are growing older, they tend to care less about knowledge of cholera disease. The apparent knowledge of cholera in the younger age group may be due to probable exposure to other cultures and information through various channels, mass and social media. The younger people may also not have been very sincere in their response. However, this finding of age difference in cholera knowledge supports the findings in similar studies carried out in Bangladesh (Wahed, Kaukab, Saha et al, 2013; Amir, Bin, Rosdi1, Azlina, Rahman \& Haque, 2019) where younger age group had higher score of cholera knowledge. Table 3 shows the t-test analysis between male and female participants on knowledge of cholera disease. The calculated t-value is 98.37 which is higher than the critical t-value of 1.96 $(98.37>1.96)$. Also, the observed probability is 0.020 and this is less than $0.05(\mathrm{P}<.05)$ probabilities for a 2-tailed test. Hence, the null hypothesis is thereby rejected. This means there is a significant difference in knowledge of cholera disease between male and female participants of Durumi community. The relationship between gender and knowledge was also significant. In the gender analysis, the t-test shows that the female gender contributed a higher score to the 
knowledge of cholera. This may be due to the women's role of being the ones to care of the sick people in the family especially children who are more susceptible to cholera because of their lowered immune system. Usually, most men may not have the knowledge as the women because they tend to be more involved in socials and other commitments outside homes. This assertion is supported by Rancourt (2013) who pointed out in his study that although the linkages between gender and vulnerability to cholera are not well understood but their feminine role gives them a greater influence over cholera prevention and treatment within the household However, the finding is at variance with the finding of Amir et al (2019), where they reported that gender did not have a significant effect on knowledge in a similar study carried out in Bangladesh. Therefore more studies on the relationship between gender and knowledge of cholera is needed to properly establish the linkages.

Table 3: T-test Analysis relationship between Gender and Knowledge of Cholera Disease

\begin{tabular}{|c|c|c|c|c|c|c|c|}
\hline Gender & $\mathbf{N}$ & $\overline{\bar{x}}$ & S.D & $\begin{array}{l}\text { Calculated } \\
\text { t-value }\end{array}$ & $\begin{array}{l}\text { Critical } \\
\text { t-value }\end{array}$ & $\begin{array}{l}\text { P } \\
\text { Sig.(2-tailed) }\end{array}$ & Decision \\
\hline Male & 159 & 19.07 & 3.20 & 98.37 & 1.96 & 0.020 & Reject $\mathrm{H}_{0}$ \\
\hline Female & 171 & 19.21 & 3.59 & & & & \\
\hline \multicolumn{8}{|c|}{$* \mathrm{P}<0.05$} \\
\hline \multicolumn{2}{|c|}{ Model } & \multicolumn{2}{|c|}{ Sum of Squares } & df & Mean Squa & $\mathbf{F}$ & Sig. \\
\hline \multirow{3}{*}{\multicolumn{2}{|c|}{$\begin{array}{l}\text { Regression } \\
\text { Residual } \\
\text { Total }\end{array}$}} & \multicolumn{2}{|c|}{33.016} & 6 & 9.403 & \multirow[t]{3}{*}{14.877} & \multirow[t]{3}{*}{0.000} \\
\hline & & & & 324 & 6.293 & & \\
\hline & & & & 330 & & & \\
\hline
\end{tabular}

\begin{tabular}{|c|c|c|c|c|c|}
\hline Model & $\begin{array}{l}\text { Unstandardized } \\
\text { Coefficient }\end{array}$ & $\begin{array}{l}\text { Standardized } \\
\text { Coefficient }\end{array}$ & $\mathbf{T}$ & Sig. & \\
\hline & Beta & Std. Error & Beta & & \\
\hline (Constant) & 6.375 & 0.511 & & 1.308 & .000 \\
\hline Primary & 3.301 & .472 & .216 & 1.597 & .023 \\
\hline Secondary & 2.034 & .421 & .309 & 2.112 & .006 \\
\hline Tertiary & 0.984 & .658 & .325 & 2.291 & .000 \\
\hline $\begin{array}{l}\text { No formal } \\
\text { education }\end{array}$ & 1.620 & .593 & .092 & 0.366 & .057 \\
\hline
\end{tabular}

From table $4 \mathrm{a}$ above, value of $\mathrm{R}$-square is .425 shows that $42.5 \%$ variation in participants' knowledge of cholera disease due to their education status. Fstatistics were carried out to find the overall strength of the model. The value of F-statistics 14.877 shows that there is significant relationship between participants' education status and knowledge of cholera disease. The result of table $4 \mathrm{~b}$ above shows relative knowledge of cholera disease as regards participants' education status: Primary education $(\beta=$ $.216 ; \mathrm{P}<.05)$; Secondary education $(\beta=.309 ; \mathrm{P}<.05)$; Tertiary education $(\beta=.325 ; \mathrm{P}<.05)$ and No formal education $(\beta=-.092 ; \mathrm{P}>.05)$. The relationship between education and knowledge shows that people with formal education appear to have more knowledge than the people with no formal education. Participants with tertiary, secondary and primary education had significant effect on knowledge of cholera disease while those with no formal education did not have significant effect on knowledge. This implies that formal education plays a key role in this regard. This is expected because education helps people to keep abreast of knowledge. The finding supports the finding of Orimbo et al. (2020), where they reported that formal education influences the knowledge of cholera in a study they carried out in Kenya in 2018. It is advised that deliberate efforts should be made to give the people health education to increase their knowledge of cholera. From table 5a above, value of $\mathrm{R}$-square is .326 shows that $32.6 \%$ variation in participants' knowledge of cholera disease due to their religions. F-statistics were carried out to find the overall strength of the model. The value of F-statistics 11.590 shows that there is significant relationship between participants' religion and knowledge of cholera disease. Table $5 \mathrm{~b}$ above shows relative knowledge of cholera disease as regards participants' religions: Christianity $(\beta=.397 ; \mathrm{P}<.05)$; Islam $(\beta=$ $.279 ; \mathrm{P}<.05)$ and $(\beta=.034 ; \mathrm{P}>.05)$. From the analysis, both Christian and Muslim participants had significant effect of knowledge of cholera disease while those practicing traditional religion were insignificant. This may be due to their religion belief. The religion association of the people to knowledge shows that Christians and Muslims have effect on knowledge but the traditional religion has no effect on knowledge. This finding about the Christians and Muslim being knowledgeable about cholera confirms 
the report of Mpazil and Mnyika (2005) in a study they carried out on the knowledge of cholera in Dar ES Salaam Region of Tanzania and they reported and Christians and Muslims had more cholera knowledge. Religion to a large extent modulates practices and behaviour. It is therefore not surprising that Christianity and Islam appear to have effect on knowledge because these two religions preach care and love of neighbours which is expected to make their followers sensitive to the needs of others, and may be able to collaborate to curb the spread of cholera. It is hoped that these religious group really work together to stop cholera infection through their heads. Although in a previous study in Cameroon, Ngwa et al. (2017) reported that Muslims preferred to copy verses from the Quran, dip them in water and offer as remedy to diseases including cholera. This and other unscientific practices by any of the religious groups may inhibit collaboration and make it difficult to curtail the spread of cholera. Table 6a reveals that the value of R-square is .507 which indicates $50.7 \%$ variation in participants' preventive measures of cholera disease due to their ages. F-statistics was carried out to find the overall strength of the model. The value of Fstatistics 17.631 shows that there is significant relationship between participants' age and preventive measures of cholera disease.

$\mathbf{H}_{\mathrm{O} 2}$ : There is no significant relationship of demographic variables (age, gender, education and religion) on the participants' preventive measures of cholera disease

Table 5a: Relationship between participants' religion and knowledge of cholera disease

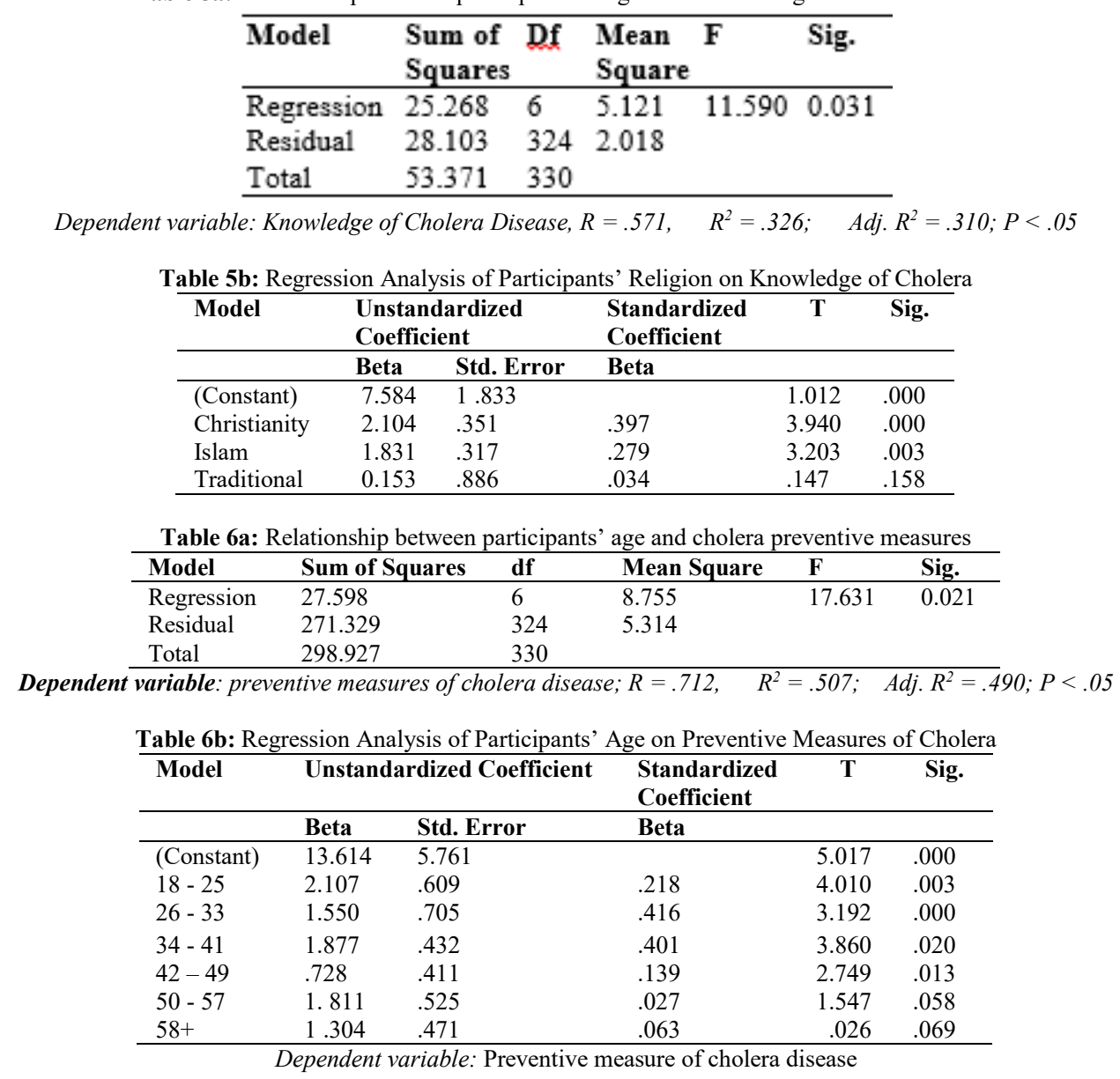

The result of table $6 \mathrm{~b}$ above shows relative preventive measures of cholera disease as regards Durumi participants' ages: $18-25(\beta=.218 ; \mathrm{P}<.05)$; 26-33 $(\beta$ $=.416 ; \mathrm{P}<.05) ; 34-41(\beta=.481 ; \mathrm{P}<.05), 42-49(\beta=$ $.139 ; \mathrm{P}<.05), 50-57(\beta=.027 ; \mathrm{P}>.05)$ and $58+(\beta=$ $-.063 ; \mathrm{P}>.05)$. From the analysis, participants from age 18 to 49 years were significantly aware of the ways to prevent cholera disease while those fall within the age groups 50 to 57 years and above were not totally aware of preventive measures of cholera disease based on the finding. Table 7 shows the statistical procedure between male and female participants on preventive measures of cholera disease. The calculated t-value is 115.08 which is higher than the critical t-value of 1.96 $(115.08>1.96)$. Also, the observed probability is 0.044 and this is less than $0.05(\mathrm{P}<.05)$ probabilities 
for a 2-tailed test. Hence, the null hypothesis is thereby rejected. This means there is indeed a significant awareness of the ways to prevent cholera disease between male and female participants of Durumi community. Table $8 \mathrm{a}$ above, value of R-square is .362 shows that $36.2 \%$ variation in participants' preventive measures of cholera disease due to their education status. F-statistics were carried out to find the overall strength of the model. The value of F-statistics 16.967 shows that there is significant relationship between participants' education status and preventive measures of cholera disease. The result of table $8 \mathrm{~b}$ above shows relative preventive measures of cholera disease as regards participants' education status: Primary education $(\beta=.259 ; \mathrm{P}<.05)$; Secondary education $(\beta$ $=.368 ; \mathrm{P}<.05)$; Tertiary education $(\beta=.349 ; \mathrm{P}<.05)$ and No formal education $(\beta=.018 ; \mathrm{P}>.05)$.
Participants with tertiary, secondary and primary education had significant preventive measures of cholera disease while those with no formal education were insignificant. This implies that nothing can be compared with formal education. Table 9a shows that the value of R-square is .346, which implies $34.6 \%$ variation in participants' preventive measures of cholera disease due to their religion. F-statistics were carried out to find the overall strength of the model. The value of F-statistics 13.475 shows that there is significant relationship between participants' religion and preventive measures of cholera disease. The result of table $9 \mathrm{~b}$ above shows relative preventive measures of cholera disease as regards participants' religions: Christianity $(\beta=.328 ; \mathrm{P}<.05)$; Islam $(\beta=.288 ; \mathrm{P}<$ $.05)$ and $(\beta=.095 ; \mathrm{P}>.05)$.

Table 7: T-test Analysis between Gender and Preventive Measure of Cholera Disease

\begin{tabular}{|c|c|c|c|c|c|c|c|}
\hline Gender & $\mathbf{N}$ & $\overline{\mathbf{X}}$ & S.D & $\begin{array}{l}\text { Calculated } \\
\text { t-value }\end{array}$ & $\begin{array}{l}\text { Critical } \\
\text { t-value }\end{array}$ & $\begin{array}{l}\mathbf{P} \\
\text { Sig.(2-tailed) }\end{array}$ & Decision \\
\hline Male & 159 & 23.02 & 2.17 & 115.08 & 1.96 & 0.044 & Reject $\mathbf{H}_{0}$ \\
\hline Female & 171 & 23.51 & 2.79 & & & & \\
\hline
\end{tabular}

Table 8a: Relationship between participants' education and preventive measures of cholera

\begin{tabular}{llllll}
\hline Model & Sum of Squares & Df & Mean Square & F & Sig. \\
\hline Regression & 43.397 & 6 & 21.289 & 16.967 & 0.000 \\
Residual & 34.644 & 324 & 13.095 & & \\
Total & 78.041 & 330 & \\
Dependent variable: Preventive Measures of Cholera Disease, $R=.602$, & $R^{2}=.362 ;$ \\
Adj. $R^{2}=.354 ; P<.05$ &
\end{tabular}

Table 8b: Regression Analysis of Participants' Education on Preventive Measures of Cholera

\begin{tabular}{llllll}
\hline Model & \multicolumn{2}{l}{$\begin{array}{l}\text { Unstandardized } \\
\text { Coefficient }\end{array}$} & $\begin{array}{l}\text { Standardized } \\
\text { Coefficient }\end{array}$ & T & Sig. \\
\hline & Beta & Std. Error & Beta & & \\
\hline (Constant) & 11.021 & 4.175 & & 4.133 & .000 \\
\hline Primary & 1.645 & .357 & .259 & 2.974 & .034 \\
\hline Secondary & 1.983 & .396 & .368 & 3.861 & .017 \\
Tertiary & 2.017 & 1.065 & .349 & 3.126 & .004 \\
No formal education & .179 & .985 & .018 & 0.169 & .065 \\
\hline
\end{tabular}

Dependent variable: Preventive Measures of Cholera Disease

Table 9a: Relationship between participants' religion and preventive measures of cholera

\begin{tabular}{llllll}
\hline Model & $\begin{array}{l}\text { Sum of } \\
\text { Squares }\end{array}$ & df & $\begin{array}{l}\text { Mean } \\
\text { Square }\end{array}$ & F & Sig. \\
\hline Regression & 18.869 & 6 & 3.964 & 13.475 & 0.004 \\
Residual & 22.579 & 324 & 1.528 & & \\
Total & 41.448 & 330 & & & \\
\hline
\end{tabular}

Dependent variable: Preventive Measures of Cholera Disease, $R=.588, \quad R^{2}=.346 ; \quad$ Adj $j . R^{2}=.327 ; P<.05$

Table 9b: Regression Analysis of Participants' Religion on Cholera Preventive Measures

\begin{tabular}{llllll}
\hline Model & $\begin{array}{l}\text { Unstandardized } \\
\text { Coefficient }\end{array}$ & $\begin{array}{l}\text { Standardized } \\
\text { Coefficient }\end{array}$ & T & Sig. & \\
\hline & Beta & Std. Error & Beta & & \\
\hline (Constant) & 8.464 & .534 & & 2.159 & .021 \\
Christianity & 2.531 & .057 & .328 & 3.852 & .003 \\
Islam & 1.922 & .052 & .288 & 3.198 & .010 \\
Traditional & 0.168 & .137 & .095 & .869 & .178 \\
\hline \multicolumn{5}{c}{ Dependent variable: Preventive Measures of Cholera Disease }
\end{tabular}

Dependent variable: Preventive Measures of Cholera Disease 
From the analysis, both Christian and Muslim participants had significant effect of preventive measures of cholera disease while those practicing traditional religion were insignificant. The second hypothesis also tested the demographic variables (age, gender, education and religion) on the preventive measures of cholera among the residents of Durumi. These variables have the same effect on preventive measures of cholera as they have on knowledge. Just like for knowledge, these findings show that the older age groups, the males, the people without formal education and people practicing traditional religion were all not significant to preventive measures of cholera just as they were not significant to the knowledge of cholera (see tables $6 \mathrm{a}, 6 \mathrm{~b}, 7,8 \mathrm{a}, 8 \mathrm{~b}, 9 \mathrm{a}$ \& 9b).

Conclusion: Demographic variables (sex, age, education and religion) have significant effect on knowledge and preventive measures of cholera. Therefore, there is an obvious need to use targeted health education to generally strengthen the people in the community who are not sufficiently knowledgeable and without adequate preventive measures (the relatively old people, the people without formal education and the traditional worshippers). Further research is encouraged in other communities that have reported cholera cases to validate the relationship of demographic variables in the disease occurrence.

Acknowledgements: I am indebted to Mr Abraham Friday for his unflinching support as a research assistant in carrying out this study. I am also grateful for the support and cooperation of Durumi residents.

\section{REFERENCES}

Abuja City Population (2019). Retrieved, from https://www.citypopulation.de/php/nigeriaadmin.php?adm1id $=$ NGA015 Accessed August 5, 2019.

Adagbada, A; Francisca, ON; Solayide, AA; Niemogha, MT; Akitoye, OC (2012). Cholera Epidemiology in Nigeria. An overview. Pan Africa Medical Journal. 1(3): 37-42.

Amir, M; Bin, F; Rosdi1, M; Azlina, N; Rahman, A; Haque, M (2019). Knowledge, Attitude, and Practice Regarding Cholera among NonAcademic Staff of International Islamic University Malaysia Kuantan Medical Campus. Bangladesh J. Med. Sci. 18 (03): 527-535.
Dan-Nwafor, CC; Ogbonna, U; Onyiah, P; Gidado, S; Adebobola, B; Nguku, P; Nsubuga, P (2019). A cholera outbreak in a rural north central Nigerian community: an unmatched case-control study. BMC Public Health. 19 (112): 1-7

Elimian, KO; Musah, A; Mezue, S; Oyebanji, O; Yennan, S; Jinadu, A; Williams, N; Ogunleye, A; Fall, IS; Yao, M; Eteng, WE; Abok, P; Popoola, M; Chukwuji, M; Omar, LH; Ekeng, E; Balde, T; Mamadu, I; Adeyemo, A; Namara, G; Okudo, I; Alemu, W; Peter, C; Ihekweazu, C (2019). Descriptive epidemiology of cholera Outbreak in Nigeria, January-November, 2018: implications for the global roadmap strategy. BMC Public Health. 19(1): 1264- 1274

Lamond, E; Kinyanjui, J (2012). Cholera Outbreak Guidelines: Preparedness, Prevention and Control. Oxfam GB. Pg. 33. https://www.unicef.org/cholera/Annexes/Support ing Resources/Annex_6B/OXFAM_Cholera guidelines.pdf

Leckebusch, GC; Abdussalam, AF (2015). Climate and socioeconomic influences on interannual variability of cholera in Nigeria. Health \& Place. 34: $107-117$.

Mpazi1, VM; Mnyika, KS (2005). Knowledge, Attitudes and Practices Regarding Cholera Outbreaks in Ilala Municipality of Dar ES Salaam Region, Tanzania. East African Journal of Public Health. 2 (2): 6-11.

National Population Commission (NPC) (2018). Population estimate. Available from https://www. nationalpopulation. gov.ng Accessed January, 2018.

Ncube, A; Jordaan, AJ; Mabela, BM (2016). Assessing the knowledge, attitudes and Practices regarding cholera preparedness and prevention in GaMampuru village, Limpopo, South Africa. Jamba. 8(2): $164-172$

Ngwa, MC; Young, A; Liang, S; Blackburn, J; Mouhaman, A; Morris, JG Jr (2017). Cultural influences behind cholera transmission in the Far North Region, Republic of Cameroon: a field experience and implications for operational level planning of interventions. Pan Afr. Med J. 28 (311): $1-10$. 
Orimbo, EO; Oyugi, E; Dulacha, D; Obonyo, M; Hussein, A; Githuku, J; Owiny, M; Gura, Z (2020). Knowledge, attitude and practices on cholera in an arid county, Kenya, 2018: A mixedmethods approach. PLoSONE 15(2): 1-14. e0229437

Rancourt, N (2013). Gender and Vulnerability to Cholera in Sierra Leone. Oxfam GB. Pg. 19. https://oxfamilibrary.openrepository.com/bitstrea $\mathrm{m} /$ handle/10546/293965/rr-gender-choleravulnerability-sierra-leone-170613en.pdf? sequence $=4 \&$ isAllowed $=y$

Stoltzfus, JD; Carter, JY; Akpinar-Elci, M; Matu, M; Kimotho, V; Giganti, MJ; Langat, D; Elci, OC (2014). Interaction between climatic, environmental, and demographic factors on cholera outbreaks in Kenya. Infect. Dis .Pov. 3 (37): $1-9$
United Nations Office for the Coordination of Humanitarian Affairs (OCHA) (2017). Nigeria: Cholera Outbreak - 2017-2019. Available from https://www.humanitarianresponse.info/en/disast er/ep-2017-000077-nga Accessed June 6, 2019.

United Nations International Children's Emergency Fund (UNICEF) (2019). Cholera Epidemiology and Response Factsheet Nigeria. Available from https://www.unicef.org/ cholera/files/UNICEFFactsheet-Nigeria-EN- FINAL.pdf. Accessed June 6, 2019.

Wahed, T; Kaukab, SST; Saha, NC; Khan, IA; Khanam, F; Chowdhury, F; Saha, A; Khan, AI; Siddik, AU; Cravioto, A; Qadri, F; Uddin, J (2013). Knowledge of, attitudes toward, and preventive practices relating to cholera and oral cholera vaccine among urban high-risk groups: findings of a cross-sectional study in Dhaka, Bangladesh. BMC Public Health. 13:242 - 